\title{
Effects of testosterone and oestrogen on serum prolactin in the androgen-insensitive rat
}

\author{
P. W. Weidenbach, J. E. Allison, R. R. Becker and R. Hollander \\ Department of Anatomical Sciences, University of Oklahoma Health Sciences Center, \\ Oklahoma City, Oklahoma 73190, U.S.A.
}

\begin{abstract}
Summary. Serum prolactin levels in intact, castrated, and castrated adrenalectomized normal and male pseudohermaphrodite (Tfm) rats were compared before and after administering testosterone oenanthate and oestradiol benzoate. Without steroids, castration alone and castration plus adrenalectomy effected a drop in prolactin titres which was greater in the castrated-adrenalectomized rats. Although testosterone did not raise the prolactin titres in any of the animals studied, oestrogen raised them far above normal in all. The fall in prolactin following castration and castration + adrenalectomy could be the result of removal of organs that were producing oestrogen.
\end{abstract}

\section{Introduction}

Male pseudohermaphrodite (Tfm) rats, although genetic males, lack Wolffian and Müllerian derivatives. Such males have a small blind vagina and nipples along the milk lines, but the testes are situated in the inguinal region because there is no scrotum.

Although exhibiting higher circulating testosterone levels than in normal rats (Naess et al., 1976), Tfm rats are reported to have generalized end-organ insensitivity to androgen (Bardin, Bullock, Schneider, Allison \& Stanley, 1970; Allison, Chan, Stanley \& Gumbreck, 1970). In spite of this, serum LH and FSH titres increase after castration (Sherins, Bullock, Gay, VanhaPerttula \& Bardin, 1970). After injection of pharmacological amounts of testosterone, LH and FSH levels decrease (Naess et al., 1976). Prolactin levels are not significantly different from those in the normal male (Goldman, Root, Duckett \& Shapiro, 1975). The testes of the Tfm rat produce oestrogen in measurable amounts (Shapiro \& Goldman, 1975).

To determine whether (1) the prolactin-regulating mechanism in $T f m$ rats also reacts to steroids and (2) loss of oestrogen could be the reason for the rise in LH and FSH after castration, serum prolactin levels were measured before and after administering testosterone oenanthate or oestradiol benzoate to intact, castrated, and castrated and adrenalectomized normal and $T f m$ animals

\section{Materials and Methods}

The rats were of the King $\times$ Holtzman strain from the Stanley-Gumbreck colony in Oklahoma City. They were kept at constant temperature and in $14 \mathrm{~h}$ light $/ 24 \mathrm{~h}$. Purina laboratory chow and water were provided ad libitum. Castration was effected through a midline incision in the anterior abdominal wall just in front of the pubis and adrenalectomy through bilateral incisions in the dorsolateral body wall just caudal to the ribs. Water bottles for adrenalectomized animals contained $0.9 \%(\mathrm{w} / \mathrm{v}) \mathrm{NaCl}$ solution. The anaesthesia for surgery was induced by i.p. injection of sodium pentobarbitone $(4 \mathrm{mg} / 100 \mathrm{~g}$ body weight). 
A minimum of 5 animals (Table 1) was used for each category. For subcutaneous injections, the steroids were suspended in sesame oil. Animals given testosterone oenanthate received $2 \mathrm{mg} / 100 \mathrm{~g}$ body weight and those given oestradiol benzoate received $20 \mu \mathrm{g} / 100 \mathrm{~g}$ body weight. The injections were given each day between 10:00 and 10:30 h for 12 days and the rats were killed $24 \mathrm{~h}$ after the last injection. All were killed by decapitation with a guillotine at 130 to 180 days of age, between 10:00 and 10:30 h. The rats were undisturbed for at least $8 \mathrm{~h}$ before decapitation. Trunk blood was collected in tubes coated with ethylene-diamine-tetraacetic acid. The supernatant was divided among serum vials, flash frozen and placed at $-20^{\circ} \mathrm{C}$ until assayed. Prolactin was measured by radioimmunoassay kits supplied by the NIAMDD Rat Pituitary Program. Rat-prolactin-RP1 was used as a standard. Three different dilutions of each sample were assayed and each dilution was duplicated. The intra-assay variation was $9 \cdot 1 \%$. The sensitivity of the assay was $1.32 \mathrm{ng} / \mathrm{ml}$. The $\Delta^{4}$-androsten-17 $\beta$-ol-one oenanthate and $\beta$-oestradiol-3benzoate were obtained from Sigma Chemical Company (St Louis, Missouri, U.S.A.). These hormones were tested by thin-layer chromatography and found to be pure. Significance of differences was calculated using Student's $t$ test.

\section{Results}

The serum protactin levels obtained are shown in Table 1. The difference between intact untreated normal and intact untreated $T f m$ rats was not significant $(P=0 \cdot 1)$. The $P$ value for the difference in prolactin levels between untreated normal castrated and castrated-adrenalectomized animals was 0.1 , whereas that for their $7 f m$ counterparts was $<0.01$. Compared to testosterone oenanthate, oestradiol benzoate caused significant $(P=0.001)$ increases in prolactin in all animals studied.

Table 1. Mean \pm s.e.m. concentration of prolactin ( $\mathrm{ng} / \mathrm{ml}$ serum) in normal and $T f m$ rats (no. in parentheses)

\begin{tabular}{|c|c|c|c|}
\hline $\begin{array}{c}\text { Animals and } \\
\text { group }\end{array}$ & $\begin{array}{c}\text { No } \\
\text { treatment }\end{array}$ & $\begin{array}{l}\text { Testosterone } \\
(2 \mathrm{mg} / 100 \mathrm{~g})\end{array}$ & $\begin{array}{c}\text { Oestrogen } \\
(20 \mu \mathrm{g} / 100 \mathrm{~g})\end{array}$ \\
\hline Normal & ${ }^{2} 19.9 \pm 1.9(10)$ & ${ }^{\mathrm{a}} 24.1 \pm 0.1(6)$ & ${ }^{\mathrm{a}} 513.3 \pm$ \\
\hline Normal castrated & ${ }^{\mathrm{b}} 12 \cdot 3 \pm 1 \cdot 2(12)$ & ${ }^{2} 28.0 \pm 4.7(6)$ & b733.8 $\pm 84.9(6)$ \\
\hline $\begin{array}{l}\text { Normal castrated } \\
\quad+\text { adrenalectomized }\end{array}$ & $8.6 \pm 1.4(6)$ & $25.9 \pm 4.1(6)$ & b756.8 $\pm 234.8(6)$ \\
\hline$T f m$ & a $32.9 \pm 7.3(9)$ & ${ }^{8} 23.3 \pm 2.5(6)$ & ${ }^{a} 502.5 \pm 62 \cdot 1(6)$ \\
\hline Tf $m$ castrated & a $18.4 \pm 2.4(5)$ & $29.5 \pm 2.0(6)$ & ${ }^{6} 911.3 \pm 184.6(7)$ \\
\hline $\begin{array}{l}\text { Tf } m \text { castrated }+ \\
\text { adrenalectomized }\end{array}$ & ${ }^{c} 11.7 \pm 0.6(7)$ & ${ }^{b} 12.8 \pm 4.6(6)$ & $429.3 \pm 56.3(6)$ \\
\hline
\end{tabular}

Within columns, values with different superscript letters are significantly different, $P<0.01$.

\section{Discussion}

The observation that pharmacological doses of testosterone oenanthate cause a significant increase in serum prolactin levels in castrated normal male rats, but not in their Tfm counterparts, supports the conclusion by Naess et al. (1976) that fewer than normal cytosol binding sites are present in the androgen receptor cells of the hypothalamus in the $T f m$ rat. Prolactin levels were greatly increased in normal and $T f m$ rats after administration of oestrogen. Since the Tfm rat testis produces measurable amounts of oestrogen (Shapiro \& Goldman, 1975), and since their tissues are generally androgen insensitive, the increase in LH and FSH and decrease in prolactin serum levels following castration may involve removal of a source of oestrogen, not testosterone. 
Since serum prolactin levels following castration and adrenalectomy were lower than after castration alone, adrenalectomy may also remove a small source of oestrogen. This decrease is greater in $T f m$ animals than in normal rats, suggesting that the $T f m$ adrenal secretes more oestrogen than normal. This is supported by the observation of Chung, Allison, Stanley \& Gumbreck (1973) that the zona fasciculata and zona reticulata in $T f m$ rats are wider than in normal rats.

The present research was supported by NIH Grant 1 R01CA17855-0121.

\section{References}

Allison, J.E., Chan, F., Stanley, A.J. \& Gumbreck, L.G. (1970) Androgen insensitivity in male pseudohermaphrodite rats. Endocrinology 89, 615-617.

Bardin, C.W., Bullock, L.P., Schneider, G., Allison, J.E. \& Stanley, A.J. (1970) Pseudohermaphrodite rat: end organ insensitivity to testosterone. Science, N.Y. 167, 1136-1137.

Chung, K.W., Allison, J.E.., Stanley, A.J. \& Gumbreck, L.G. (1973) Effects of adrenocorticotropic hormone and gonadotropins on urinary 17-ketosteroid production in the male pseudohermaphrodite rat. Fert. Steril. 24, 677-686.

Goldman, A.S., Root, A.W., Duckett, G. \& Shapiro, B.H. (1975) Pituitary hormone secretion in the genetically male rat. J. Endocr. 64, 249-255.
Naess, O., Haug, E., Attramadal, A., Aakvaag, A., Hansson, V. \& French, F. (1976) Androgen receptors in the anterior pituitary and central nervous system of the androgen insensitive ( $\mathrm{tfm}$ ) rat: correlation between receptor binding and effects of androgens on gonadotropin secretion. Endocrinology 99, 1295-1303.

Shapiro, H.B. \& Goldman, A.S. (1975) Testicular maintenance and masculinized development of the vagina of the androgen-insensitive male rat pseudohermaphrodite. Endocrinology 96, 1392-1395.

Sherins, R.J., Bullock, L., Gay, V.L., Vanha-Perttula, T. \& Bardin, C.W. (1970) Plasma LH and FSH levels in the androgen insensitive pseudo-hermaphrodite rat. Endocrinology 88, 763-770.

Received 27 April 1979 